\title{
Uma alma entre dois corpos A amizade cristã como processo de humanização e manifestação do amor de Deus na Oração 43,14-24 de São Gregório de Nazianzo
}

\author{
Orientador: Paulo Cezar Costa \\ Mestrando: Darlan Aurélio de Aviz \\ Área de Concentração: Teologia Sistemático-Pastoral \\ Linha de Pesquisa: Fé e Cultura
}

A amizade é um fenômeno universal e próprio da condição humana que nasce da livre oferta de si mesmo para lançar-se ao mistério do outro. Por meio dela, os homens tornam-se capazes de encontrar um caminho para a sua humanização. Este trabalho, sob a perspectiva da teologia patrística, retrata a amizade de Gregório de Nazianzo e Basílio de Cesaréia, como um modelo para todo o cristão que busca uma experiência existencial do amor, revestida da Aliança que Deus faz com a humanidade. Para tal, investigou-se sistematicamente a temática da philia cristã, à luz desses dois padres capadócios que fizeram uma grande síntese do pensamento clássico e cristão no século IV. Essa dissertação se fundamenta na Oração 43 de Gregório de Nazianzo, especificamente nos parágrafos 14 a 24, que retrata duas personalidades tão distintas, movidas pela busca da expressão mais sensível do amor de Deus, capazes de viver uma comunhão universal e indivisível, tornadas "como uma alma em dois corpos" a ponto de ser imperceptível a costura que as uniu. Objetiva-se, portanto, demonstrar a relevância da amizade cristã na Oração 43,14-24 como importante instrumento no processo de humanização e de renovação das relações fraternas.

Palavras-chave: Philia. Amizade Cristã. Aliança. 